\title{
PEMETAAN KESIAPAN IMPLEMENTASI PENDEKATANAN SAINTIFIK DI SMP
}

\author{
Mustofa
}

\author{
Email: mustofa.fis@um.ac.id
}

\begin{abstract}
Abstrak: Di tingkat SMP, kurikulum 2013 menekankan pada implementasi pendekatan saintifik dengan mengintegrasikan karakter. Kebijakan Mendikbud dalam melakukan perubahan kurikulum dari KTSP beralih ke Kurikulum 2013 masih menimbulkan pro dan kontra dari banyak kalangan. Pelaksanaan Kurikulum 2013 tersebut menghadapi banyak masalah. Penelitian deskriptif evaluative ini dimaksudkan untuk memetakan permasalahan implementasi Kurikulum 2013 yang selanjutnya dapat dijadikan dasar pengembangan model tindakan perbaikan oleh pihak terkait. Penelitian ini menggunakan teknik area purposive sampling, dengan sampel terpilih SMP di Kabupaten Blitar. Pengumpulan data dilakukan melalui observasi, wawancara, dan pengisian angket. Analisis data dilakukan melalui proses pemetaan yang meliputi identifikasi, kategorisasi dan eksplanasi. Berdasarkan teknik analisis data tersebut diperoleh hasil (1) pemahaman guru tentang kurikulum 2013, khususnya dalam pembelajaran dengan pendekatan saintifik belum memadai, (2) guru masih menerapkan pembelajaran konseptual, belum optimal dalam menerapkan pendekatan saintifiki,(3) guru belum memahami sepenuhnya dalam melaksanakan evaluasi, dan (4) guru memerlukan penyamaan persepsi tentang pembelajaran saintifik.
\end{abstract}

Kata Kunci: Kesiapan, Kurikulum 2013, SMP

\section{PENDAHULUAN}

Upaya peningkatan kualitas pendidikan dilakukan dengan perbaikan sistem pendidikan yang ada, dalam hal ini pemerintah dan sekolah memiliki peran yang sangat penting. Pemerintah berhak membuat kebijakan-kebijakan dibidang pendidikan sedangkan sekolah sebagai tempat untuk menjalankan kebijakan dari pemerintah yaitu menyelenggarakan pendidikan (Setiawan, 2010).

Salah satu kebijakan yang dilakukan adalah perubahan kurikulum. Kurikulum merupakan alat mencapai suatu tujuan dan membutuhkan keandalan penggunanya. Sama seperti kendaraan apa pun, banyak ketidaksempurnaan dalam setiap kurikulum. Dalam perspektif kepentingan bangsa dan negara, kendaraan kurikulum ini akan berfungsi dan berperan baik jika para pelaku dan pemerhati memiliki kejelasan tujuan dan visi bersama, peta jalan yang benar, serta keandalan dalam pemanfaatan kendaraan (Lie, 2013). Kurikulum terakhir yang digunakan dalam pendidikan di Indonesia saat ini adalah Kurikulum Tingkat Satuan Pendidikan (KTSP). KTSP memiliki keunggulan berupa kebebasan bagi penyelenggara pendidikan setiap daerah di Indonesia yang berbeda. Pada dasarnya setiap daerah memiliki keunggulan masing-masing yang perlu ditingkatkan. Peningkatan tersebut dapat melalui kurikulum dalam pendidikan yang digunakan. Meskipun memiliki kelebihan tersebut, KTSP dalam implementasinya 
memiliki beberapa kelemahan. Kelemahan utama pada implementasi KTSP adalah kurangnya penguatan karakter dan adanya potensi untuk disisipi ajaran sesat (Puskur Kemendikbud, 2012). Perubahan kurikulum yang akan diberlakukan pada pertengahan 2013 dan diberlakukan di seluruh kelas di seluruh jenjang pendidikan dasar dan menengah pada tahun 2014 , mencakup pengurangan mata pelajaran, pengurangan materi pelajaran, menambah jam belajar, penguatan pelaksanaan kurikulum berbasis kompetensi dalam pembelajaran, penguatan pengetahuan, keterampilan, dan sikap secara holistik dalam pembelajaran, penguatan pembelajaran siswa aktif dengan berbagai sumber belajar, dan penguatan penilaian proses dan hasil, serta tanggap terhadap perubahan sosial yang terjadi pada tingkat lokal, nasional, dan global. Disamping itu, mengacu pada standar proses sebagaimana diatur dalam Permendikbud No. 65 Tahun 2013 tentangStandar Proses Pendidikan Dasar dan Menengah telah mengisyaratkan tentangperlunya proses pembelajaran yang dipandu dengan kaidah-kaidah pendekatan saintifik/ilmiah. Upaya penerapan Pendekatan saintifik filmiah dalam proses pembelajaran ini sering disebut-sebut sebagai ciri khas dan menjadi kekuatan tersendiri dari keberadaan Kurikulum 2013, yang tentunya menarik untuk dipelajari. Oleh karena itu guru sebagai ujung tombak implementasi kurikulum 2013 harus memiliki kompetensi yang memadai tentang implementasi pendekatan saintifik/ilmiah dalam pembelajaran di sekolah.

Di tingkat SMP, kurikulum 2013 menekankan pada implementasi pendekatan saintifik dengan mengintegrasikan karakter. Kebijakan Mendikbud dalam melakukan perubahan kurikulum dari KTSP beralih ke Kurikulum 2013 masih menimbulkan pro dan kontra dari banyak kalangan. Terkait tentang kontra atau tidak setuju pelaksanaan kurikulum 2013 ini sangat beralasan. Penerapan atau perubahan kurikulum yang cenderung tergesa-gesa ini akan banyak menimbulkan banyak permasalahan, baik dari jenjang SD, SMP, SMA dan SMK. Dari semua jenjang tersebut kemungkinan besar akan mengalami banyak kendala dari penerapan kurikulum 2013.

Perubahan kebijakan kurikulum pendidikan pada jenjang sekolah Menengah Pertama memiliki pengaruh yang sangat besar terhadap perkembangan pendidikan di Indonesia. Temuan lapangan mengenai implementasi standar isi ditemukan beberapa aspek yang menjadi kendala pelaksanaannya. Misalnya mata pelajaran Senibudaya dan ketrampilan, sekolah tidak memiliki guru dengan spesifikasi/kualifikasi keahlian bidang tersebut. Perubahan kurikulum nasional akan sangat berdampak pada perkembangan kualitas pendidikan di Indonesia, kesiapan seluruh elemen pendidikan menjadi suatu tugas yang besar bagi pemerintah. Sebab jika perubahan kurikulum dan tujuan peralihan kurikulum baru ini tidak dilakukan dengan persiapan yang matang akan mengorbankan dunia pendidikan di Indonesia. Sebelum penerapan kurikulum 2013 dilaksanakan pemerintah harus benar-benar mengetahui kesiapan seluruh elemen pendidikan di Indonesia, sentralisasi kurikulum 2013 bagaimanapun juga telah berdampak pada pembatasan kreatifitas dan inovasi pendidik di 
wilayahnya masing-masing (pembatasan ini akan menyebabkan beberapa sentral aktivitas dalam rangka pengembangan kompetensi pendidik di masing-masing wilayah akan mati), adaptasi pada peserta didik dengan perubahan kurikulum tersebut juga perlu diperhatikan karena karakter peserta didik masing-masing daerah di Indonesia berbeda, serta perubahan kurikulum yang bersifat sentralis seperti ini akan cenderung menghabiskan dana anggaran pemerintah yang baru dan tidak sedikit.

Beberapa hasil penelitian menunjukkan pelaksanaan pembelajaran tematik selama ini sulit dilaksanakan (Harsiati, 2009). Hasil penelitian Noldy (2010) juga menunjukkan bahwa guru belum melaksanakan pembelajaran tematik dengan beragam alasan. Hasil-hasil penelitian lain juga tidak jauh berbeda. Demikian juga untuk jenjang SMP dituntut mengintegrasikan karakter pada pembelajarannya, dan mengikuti isyarat permendikbut 65 tentang standar proses yang mengisaratkan dilakukannya kaidah-kaidah saintifik dalam pembelajaran yang secara praktis sangat sulit bagi guru. Hal tersebut menunjukkan bahwa di lapangan guru membutuhkan persiapan dan kesiapan untuk implementasi kurikulum tersebut.

Pengawalan implementasi kurikulum 2013 yang telah diuji cobakan pada sekolah model telah dilakukan beberap kegiatan antara lain pengadaan buku ajar dan buku pegangan guru, pelatihan bagi guru, kepala sekolah, pengawas, dan pendampingan kepada sekolah sasaran, evaluasi dan monitoring.

Hasil Monitoring dan Evaluasi Implementasi Kurikulum 2013, khususnya untuk SMP dengan paparan hasil sebagai berikut. Penerapan pendekatan saintifik dalam proses pembelajaran di dalam kelas belum sesuai yang diharapkan, secara statistik diperoleh data sebagai berikut;. Guru SMP $12 \%$ belum sesuai, $56 \%$ sesuai dan $32 \%$ sangat sesuai. Pemahaman Guru tentang Penilaian Otentik dan aplikasinya dalam proses pembelajaran di dalam kelas, menurut kepala sekolah diperoleh data sebagai berikut; Guru SMP $3 \%$ belum sesuai, $16 \%$ sesuai dan $81 \%$ sangat sesuai. Pemahaman Guru tentang pembelajaran remedi dan pengayaan bagi peserta didik yang memerlukannya dalam proses pembelajaran di dalam kelas telah dipahami oleh guru. Menurut kepala sekolah diperoleh data sebagai berikut; Guru SMP $15 \%$ belum sesuai, $52 \%$ sesuai dan $33 \%$ sangat sesuai. Pemahaman Guru tentang konsep dan aplikasi penilaian diri, menurut Kepala Sekolah, cukup dipahami guru. Guru SMP $15 \%$ belum sesuai, $49 \%$ sesuai dan $36 \%$ sangat sesuai.

Menurut pandagan siswa (peserta didik); cara guru menyampaikan materi dipahami dengan mudah, menarik dan menyenangkan selama proses pembelajaran berlangsung. Hal ini dapat dilihat dari data yang telah sesuai harapan, yaitu; SMP; 91\%, Sedangkanlebih detail ditemukan catatan bahwa pembelajaran saintifik masih diartikan guru masuk ke kelas dan menugaskan siswa untuk presentasi, menurut siswa guru belum kreatif untuk mendorong minat belajar siswa, masih diartikan guru hanya melakukan kegiatan ritual saja.

Guru memberi kesempatan siswa untuk mengamati, merumuskan pertanyaan, mengumpulkan data/informasi, mengolah data/informasi, dan mengomuni- 
kasikan, dalam hal ini melakukan proses pembelajaan, guru telah menerapkan pendekatan pembelajaran berbasis pendekatan saintifik. Data tersebut dapat dicermati melalui informasi data sebagai berikut: SMP; 86\%, Bahkan secara detail ditemukan bahwa keterkaitan antar Kompetensi Inti (KI) kurang dimengerti oleh guru (KI 1 dan KI 2), pembelajaran projek masih menjadi kendala bagi guru. Guru belum memahami materi metakognisi. Waktu yang tersedia dirasakan tidak cukup untuk menyampaikan seluruh materi.

Mencermati hasil monitoring dan evaluasi khususnya proses pembelajaran di sokolah, maka perlu dicarikan solusi untuk tindak lanjut implementasi kurikulum 2013 di tahun 2014. Bagaimana implementasi kurikulum 2013 tersebut untuk SMP di Kabupaten Blitar belum terpetakan.

Pemetaan kesiapan implementasi kurikulum 2013 ini penting dan strategis karena dua alasan: Pertama, sampai saat ini pelatihan kurikulum 2013 belum dilaksanakan secara tuntas. Wawancara pendahuluan dengan kepala UPTD Wonodadi diperoleh informasi awal bahwa tahapan pelatihan implementasi kurikulum baru sampai tahap pengembangan dampak pelatihan ( guru inti yang telah dilatih ditugasi melatih guru yang lain) sehingga masih banyak sekolah yang belum siap mengimplementasikan kurikulum 2013. Kedua, terpetakannya kendala implementasi kurikulum 2013 ini memberi arah dinas dan pihak terkait untuk memberdayakan sekolah-sekolah yang belum siap melaksanakan kurikulum 2013 melalui pelatihan kurikulum baik melalui program dinas pendidikan maupun melalui program pengabdian kepada masyarakat dosen sebagai penerapan IPTEK.

\section{METODE}

Rancangan penelitian ini menggunakan penelitian survey yang dimulai dari menyusun instrumen survey dalam bentuk angket semi terbuka untuk menjaring permasalahan guru SMP dalam mengimplementasikan kurikulum 2013. Selanjutnya instrumen digunakan untuk mensurvey permasalahan yang dihadapi guru dalam mengimplementasikan kurikulum 2013 terutama terkait dengan implementasi pendekatan saintifik dalam pembelajaran. Populasi penelitian adalah SMP Negeri dan Swasta di di Kabupaten Blitar, dengan 3 area sample berdasar ring area. Ring 1 daerah yang berada dipusat kota, ring 2 daerah tengah, dan ring 3 daerah pinggiran. Sampel penelitian kemudian dikelompokkan berdasarkan kategori sekolah, yaitu SMP kategori tinggi, SMP kategori rendah. Penentuan ke dua kategori tersebut berdasarkan perolehan NEM siswa yang lulus pada tahun ajaran 2013/2014. Penetapan kategori sekolah dilakukan dengan cara mencari rata-rata NEM siswa pada masing-masing sekolah, kemudian dilanjutkan dengan pembuatan ranking. Berdasarkan urutan ranking tersebut selanjutnya ditetapkan kategori sekolah. Pada tiap kategori sekolah akan ditetapkan dua SMP sebagai sekolah sampel secara purposif. Data yang telah terkumpul dianalisis secara deskriptif. 


\section{HASIL PENELITIAN DAN PEMBAHASAN}

\section{Pola Kegiatan Saintifik}

Hasil analisis RPP dan pelaksanaan pembelajaran tematik yang dilakukan guru diperoleh beberapa pola kegiatan saintifik. Kegiatan saintifik dipilah menjadi beberapa pola yang mencakup (a) pola saintifik dengan berbasis pada pengamatan gambar ( mengamati gambar pada buku teks, mendiskusikan konsep, menyampaikan hasil), (b) pola saintifik dengan berbasis pada persiapan percobaan) mengumpulkan alat- alat, menduga, melakukan percobaan, membuat tabel, menganalisis tabel, mengomunikasikan hasil, membuat tugas pengayaan, (c) pola saintifik berbasis kegiatan bersama (menyanyi, mendengarkan penjelasan permasalahan, melakukan percobaan, diskusi kelas tentang hasil percobaan, menyimpulkan kegiatan bersama-sama), (d) pola saintifik berbasis pada kegiatan membaca/ mendengar (membaca /pemahaman) membagi kelompok untuk berdiskusi, wakil kelompok menyampaikan hasil diskusi, tugas pengayaan), dan (e) pola saintifik berbasis pada pengamatan lingkungan (mengamati lingkungan sekitar, mendiskusikan, wakil kelompok menyampaikan, penguatan). Dari pola yang ditemukan simpulan bahwa kegiatan menanya dan menalar belum dieksplorasi guru secara maksimal. Guru kesulitan merangsang siswa untuk mengajukan pertanyaan saintifik.

1. Langkah perencanaan pembelajaran tematik.

Langkah yang ditempuh guru dalam merencanakan pembelajaran tematik Kurikulum 2013 di SMP ada beberapa pola. Pola pertama mencakup kegiatan membaca buku guru, membuat RPP pada setiap PB dengan mencontoh langkah pada buku guru tanpa modifikasi. Pola kedua mencakup kegiatan membaca silabus, memetakan alokasi waktu, membuat RPP dengan langkah-langkah dari silabus. Pola ketiga mencakup kegiatan membaca buku siswa dan buku guru, dan membuat RPP dengan berdasar pada kegiatan pada buku siswa. Pola keempat mencakup kegiatan membaca contoh RPP tematik, memodifikasi RPP sesuai dengan buku guru. Pola kelima mencakup kegiatan membaca buku guru, membuat RPP pada setiap PB dengan mencontoh langkah pada buku guru. Dari hasil analisis ditemukan bahwa buku panduan guru amat penting dalam perencanaan pembelajaran tematik di SMP. Disamping itu juga belum ditemukan modifikasi langkah pembelajaran, media, dan modifikasi instrumen penilaian.

2. Kegiatan untuk Penumbuhan KI 1 dan KI 2

Kegiatan yang ditempuh guru untuk penumbuhan KI 1 adalah (a) kegiatan berdoa di awal pelajaran, dan (b) kegiatan ajakan bersyukur pada awal pembelajaran karena masih diberi kesehatan dan kesempatan belajar. Kegiatan yang ditempuh guru untuk penumbuhan KI 2 adalah (a) kegiatan diskusi untuk menumbuhkan kerjasama, (b) kegiatan mengecek kehadiran untuk menumbuhkan kedisiplinan, (c) kegiatan pemberian tugas untuk menumbuhkan tanggung jawab.

Pola integrasi KI 1 dan KI 2 masih belum variatif. Guru belum memahami cara penumbhan KI 1 dan KI 2 pada kegiatan inti, dan penutup. Cara mengintegrasikan sikap kritis, kreatif, dan 
jujur tidak ditemukan pada jawaban guru. Artinya, guru belum memiliki pemahaman dan keterampilan yang memadai untuk merancang kegiatan yang dapat menumbuhkan sikap kritis, kreatif, dan jujur.

3. Pemahaman Guru terhadap Penggunaan Buku Panduan Tematik

Guru yang berpendapat sangat mudah memahami langkah pembelajaran dalam buku tematik sebesar $78 \%$, cukup mudah $20 \%$, dan sukar $2 \%$.

4. Pendapat Guru tentang Kemampuan Mengimplementasikan Pembelajaran Tematik

Guru yang berpendapat sangat mudah mengimplementasikan langkah pembelajaran sebesar $44 \%$, cukup mudah $40 \%$, dan sukar $16 \%$. Guru yang berpendapat sangat mudah mengimplementasikan media pembelajaran sebesar $20 \%$, cukup mudah $46 \%$, dan sukar 34 $\%$. Guru yang berpendapat bahwa sangat mudah melaksanakan penilaian pada buku guru sebesar $24 \%$, cukup mudah $20 \%$, dan sukar $56 \%$.

5. Masalah yang Dihadapi Guru dalam Implementasi Pembelajaran Tematik

Dari hasil analisis diidentifikasi masalah-masalah yang dihadapi guru dalam pembelajaran tematik. Masalahmasalah itu mencakup hal-hal berikut.

Masalah dalam menggunakan buku guru mencakup, (a) ada indikator dan jaring tema yang kurang sesuai, (b) memisahkan tematik dengan PJOK karena pada buku guru menjadi satu, (c) konsep pada buku guru masih minimal terutama konsep bahasa, jaring mingguan ada yang belum sinkron.

Masalah dalam menggunakan buku siswa mencakup (a) kegiatan siswa terlalu banyak padahal waktu sedikit, (b) ada materi pada buku siswa yang kurang dipahami, (c) bermasalah dalam memilah PB dengan alokasi waktu tertentu, (d) sulit memilah kegiatan saintifik pada kegiatan pada buku guru, (e) belum dapat membuat kegiatan menalar/ asosiasi, (f) belum mampu mengintegraskan sikap kritis, kreatif, dan jujur.

Masalah dalam melaksanakan di kelas mencakup (a) murid sulit dikelola, (b) sebagaian siswa kurang bisa mengikuti metode penemuan karena minta dijelaskan dulu, (c) guru tidak menguasai berbagai konsep mata pelajaran karena terbiasa guru mata pelajaran, (d) guru belum dapat melaksanaan proyek pada minggu keempat yang dianjurkan pada buku guru dan buku siswa, (f) sulit mengintegrasikan KD dari KI 1 dan 2 dalam pelaksanaan di kelas.

Masalah dalam penilaian mencakup (a) belum bisa merencanakan penilaian dalam satu semester, (b) sulit menyusun instrumen keterampilan yang menuntut siswa berpikir tingkat tinggi, (c) penilaian terlalu banyak dan beragam sehingga ribet pelaksanaannya, (d) penilaian sikap sulit dilakukan karena waktu terbatas dan guru terkonsentrasi pada pembelajaran, dan (e) sulit mengolah hasil penilaian sikap.

\section{DAFTAR PUSTAKA}

Akhadiah, S. 1991. Bahasa Indonesia I, Jakarta: Depdikbud.

Brady, L. 1992. Curriculum Development (fourth edition). Prentice Hall: Australia

Fogarty, R. 1991. The Minful School How to Integrate the Curricula, Illinois: IRI/Skylight Publishing, Inc. 
Hamalik, O. 2003. Kurikulum dan Pembelajaran. Bumi Aksara: Jakarta

Kompas. 2012 Kurikulum 2013 Masih Pro-Kontra. (Online). (Kurikulum 2013 Masih Pro-Kontra). Diakses 7 Maret 2013.

Kompas. 2013 Kurikulum 2013 Belum Disosialisasikan di NTT. (Online). (http://jaringnews.com/politikperistiwa/umum/34924/ Kurikulum 2013 Belum Disosialisasikan di NTT). Diakses 7 Maret 2013.

Nasution. 2003. Asas-asas Kurikulum. Bumi Aksara: Jakarta

Noldy, P. 2010. PembelajaranTerpadu di Sekolah Dasar. Laporan Penelitian Universitas Negeri Jakarta.

Oliva, Peter F. 1992. Developing The Curriculum (Third edition). Harper Collins Publishers: United States.

Permindikbud No 65 tahun 2013 tentang Standar Proses.

Santrock, J.W. 1997. Life-Span Development. Chicago: Times mirror Higher Education Group Inc.

Setiawan, D.C. 2009. Penerapan Model Pembelajaran Project Based Learning (PBL) pada Mata Pelajaran Biologi untuk Memberdayakan Kemampuan Berpikir Kritis dan Sikap Siswa SMA terhadap Lingkungan Hidup. Skripsi tidak diterbitkan. Malang: FMIPA Universitas Negeri Malang.

Sudjana, Nana. 1993. Pembinaan dan Pengembangan Kurikulum di Sekolah Kejuruan. Bandung: PT SInar Baru.

Tim BSNP. 2012. Standar Nasional Pendidikan. Jakarta: Badan Standar Nasional Pendidikan.

Tim Pengembang Kurikulum Propinsi. 2008. Evaluasi Pelaksanaan KTSP. Jakarta: Pusat Kurikulum Badan Penelitian dan Pengembangan, Departemen Pendidikan Nasional.
Tribun Kaltim, 2013. Kurikulum 2013 Belum Disosialisasikan di NTT. (Online).

(http://jaringnews.com/politikperistiwa/umum/34924/ Kurikulum 2013 Masih Mentah dan Timbulkan Masalah). Diakses 7 Maret 2013.

Wilson, L, 1991. An Integrated Approach to Learning, Melbourne: Robert Anderson \& Association Ltd. 